Modern Asian Studies 39, 1 (2005) pp. 155-188. (C) 2005 Cambridge University Press DOI: 10.1017/S0026749X04001441 Printed in the United Kingdom

\title{
Labour and Neo-Liberal Globalization in South Korea and Taiwan
}

\author{
TAT YAN KONG
}

School of Oriental and African Studies, University of London

\begin{abstract}
As they increasingly embrace neo-liberal economic policies (especially since the 1997-8 Asian financial crisis), the Northeast Asian NICs of South Korea and Taiwan are now said to be losing their uniqueness as alternative capitalist models. Central to the neo-liberal project is labour flexibility. This entails the reform of employment legislation and of the wider social settlement between state, business and labour. This article will argue against the 'homogenization' thesis by revealing the distinctive political, economic and ideological characteristics that distinguish the recent market-oriented labour reforms in South Korea and Taiwan from neo-liberal transitions elsewhere. The sources of variation in the pathways of labour market reform within the Northeast Asian NICs will also be explained.
\end{abstract}

Neo-liberal globalization is said to have homogenizing effects on formerly regionally specific capitalist forms. Long depicted as an alternative model of capitalist development, the Northeast Asian NICs of South Korea and Taiwan are now said to be losing their uniqueness as they embrace neo-liberal economic policies, a transition hastened by the 1997-8 Asian financial crisis. A crucial component of the transition to neo-liberalism is the creation of flexible labour forces. This entails the reform of institutional relationships that govern flexibility, namely, the regulations specified in employment legislation and the wider state-business-labour arrangements or social settlements underpinning those rules. From the perspective of recent labour reforms in South Korea (hereinafter Korea) and Taiwan, this article will question the 'homogenization' thesis. It will do so by revealing the distinctive political, economic and ideological characteristics that mark out the recent market-oriented labour reforms in Northeast Asia from neo-liberal transitions elsewhere. Having established the continuing distinctiveness of the Northeast oo26-749X/05/\$7.50+\$0.10 
Asian pattern from capitalisms elsewhere, the variations between Korea and Taiwan will be explained.

Labour has been chosen not only because of its significance to neo-liberal transitions but also because it is a relatively neglected subject in the comparative political economy literature on East Asia. Such literature has focused on the workings of the state-business relationship. This reflected the subordination of labour at the hands of the developmental state during the years of authoritarian rule as well as the popularity of state-centric analyses that permeated political science. Labour has emerged as an autonomous political actor since democratization. The upsurge of strikes following democratization brought labour issues to scholarly attention, especially in the case of Korea. Even so, studies have tended to be country-specific and comparative studies of labour in post-authoritarian Korea and Taiwan ${ }^{1}$ remain few and far between.

\section{Labour and Neo-Liberal Globalization in Northeast Asia}

Neo-liberal globalization is commonly said to encompass the following features. First, production processes are transnationalized. Second, financial liberalization and communications technology facilitate high mobility of capital flows (especially short term speculative flows) mediated through the leading financial centres. Third, trade and investment flows are promoted through the creation of international regimes by national governments, Fourth, liberal capitalism is widely accepted as the only viable political economic form. The significance of these features (especially for the nation-state) has generated a vast and contentious literature. ${ }^{2}$

While the ever growing traffic of cross-national transactions and international trade rules render obsolete many traditional forms of

\footnotetext{
${ }^{1}$ For example, see Chang-Ling Huang, 'State Corporatism in Question: Labour Control in South Korea and Taiwan', Chinese Political Science Review (1997), pp. 2548, and Chang-Ling Huang, 'Learning the New Game: Labour Politics in the Newly Democratized South Korea and Taiwan', paper presented at the Annual Meeting of the American Political Science Association (31 August-3 September 2000).

${ }^{2}$ For a strong version of the globalization thesis, see Kenichi Ohmae, The Evolving Global Economy: Making Sense of the New World Order (Cambridge, Mass.: Harvard Business Review Books, 1995). For the counter view see: Linda Weiss, The Myth of the Powerless State (Oxford: Blackwell 1998); Paul Hirst and Grahame Thompson, Globalization in Question: The International Economy and the Possibilities of Governance (Oxford: Polity 200o).
} 
government intervention, national governments continue to be highly influential from the way they shape the local institutional environment by the setting and enforcing of rules. Given that it has become the only immobile factor of production, government and its administration of rules has paradoxically become more important than ever. National economic competitiveness in the era of globalization is arguably defined by the capacity of national governments to set institutional conditions that facilitate domestic competition and attract capital inflows. ${ }^{3}$ One such condition is the legal and social framework of labour regulations.

Studies of the advanced economies associate neo-liberal globalization with job insecurity and other destabilizing changes for labour. ${ }^{4}$ Insecurity arises from exposure to world-wide competition and the ease with which productive facilities can be transferred to more competitive locations. To prevent local capital from taking flight and to attract transnational corporation (TNG) investment, governments reform employment frameworks in ways that are conducive to the 'flexible' deployment of labour. Seen as burdens on competitiveness, the social-democratic arrangements that previously gave some influence to labour over policy are terminated. ${ }^{5}$ 'Flexible' industrial workforces have some distinctive characteristics. The profile of the workforce changes as the proportion of workers with temporary and part-time status increases. The notion of permanent employment becomes a thing of the past given the ease of investment relocation. In remuneration, performance displaces seniority as the determining criterion. In the work process, labour switches towards the performance of multiple tasks while the intensity of work (and remuneration) is varied according to market conditions.

${ }^{3}$ A vast literature exists here. For standard works see: Douglass C. North, Institutions, Institutional Change and Economic Performance (Cambridge: Cambridge University Press, 1990) (interaction between formal/informal rules and economic performance); Michael Porter, The Competitive Advantages of Nations (New York: Free Press, 1990) (institutional conditions for national competitiveness); John Stopford and Susan Strange, Rival States, Rival Firms (New York: Cambridge University Press 1991) (national competition for transnational investment).

${ }^{4}$ For example, see Richard Locke, Thomas Kochan and Michael Piore, 'Reconceptualizing Comparative Industrial Relations: Lessions from International Research', International Labour Review, 134, 2 (1995), pp. 139-61.

${ }^{5}$ On the increasing strain on societal corporatism, see for example, Peter Swenson, Fair Shares: Union, Pay and Politics in Sweden and Germany (Ithaca, NY: Cornell University Press, 1989). 
Labour unions are forced onto the defensive by neo-liberal globalization. Strikes lose their effectiveness under conditions in which business can easily relocate to find competitive workforces elsewhere. Labour unions lack the transnational solidarity commensurate with capital's mobility. Employment casualization and pay competition

KOREA
POLITICAL
ECONOMIC
ENVIRONMENT
- Military junta 1961-3
- Soft authoritarianism
1973-72
- Hard authoritarianism
1972-79
- Civilian regime 79-80
- Military coup 1980
Political liberalization
from 1983
- Constitutional
dialogue
Formal
democratization
- Democratic revolution
- Roh Tae-Woo
becomes president

- Economic growth
slows
- Anti-land
concentration campaign
- Conservative three
party merger

Economic

liberalization

accelerates

- Kim Young-Sam becomes president

- Globalization proclaimed

• Korea joins WTO

\section{KOREA \\ DEVELOPMENTS \\ IN LABOUR \\ RELATIONS}

- Labour Standards Act

1953

- Labour Dispute

Adjustment Act 1963

- Trade Union Act 1963

- Labour-Management

Council Act 1980

- Minimum Wage Act

- Great Workers'

Struggle

- Revisions to TUL and

LDAL

- Return to limited
labour repression
strategy
- Employee Welfare
Fund Act

- Basic Employment

Policy Act

- Employment

Insurance Act

- Employment Security

Act

- Industrial Safety and

Health Act
1986

$\begin{array}{ll}1987 & \text { regime } \\ \text { Formal }\end{array}$

Pre-
1986

TAIWAN

POLITICAL

ECONOMIC

ENVIRONMENT

- Martial law declared

1949

- Political liberalization

begins from 1975

- Formation of DPP

tolerated by KMT

regime

democratization

begins

- Martial law lifted

- Lee Teng-Hui succeeds as partyappointed president

1989

- First major

privatizations

1990

1991 - Legislature

1992

1993

- New Party splits from KMT

1994

Formal

democratization

completed

- Principle of direct

presidential election
TAIWAN

DEVELOPMENTS

IN LABOUR

RELATIONS

- Settlement of Labour

Disputes Law 1943

- Labour Safety and

Health Act 1974

- Factory Law 1975

- Labour Union Law

1949, 1975

- Labour Standards

Law 1984

- Labour-Management

Conference Rules 1985

- Labour disputes intensify

- SLDA amended

LSHA amended

- Employment Service Act

- National Health Insurance Act

continued 


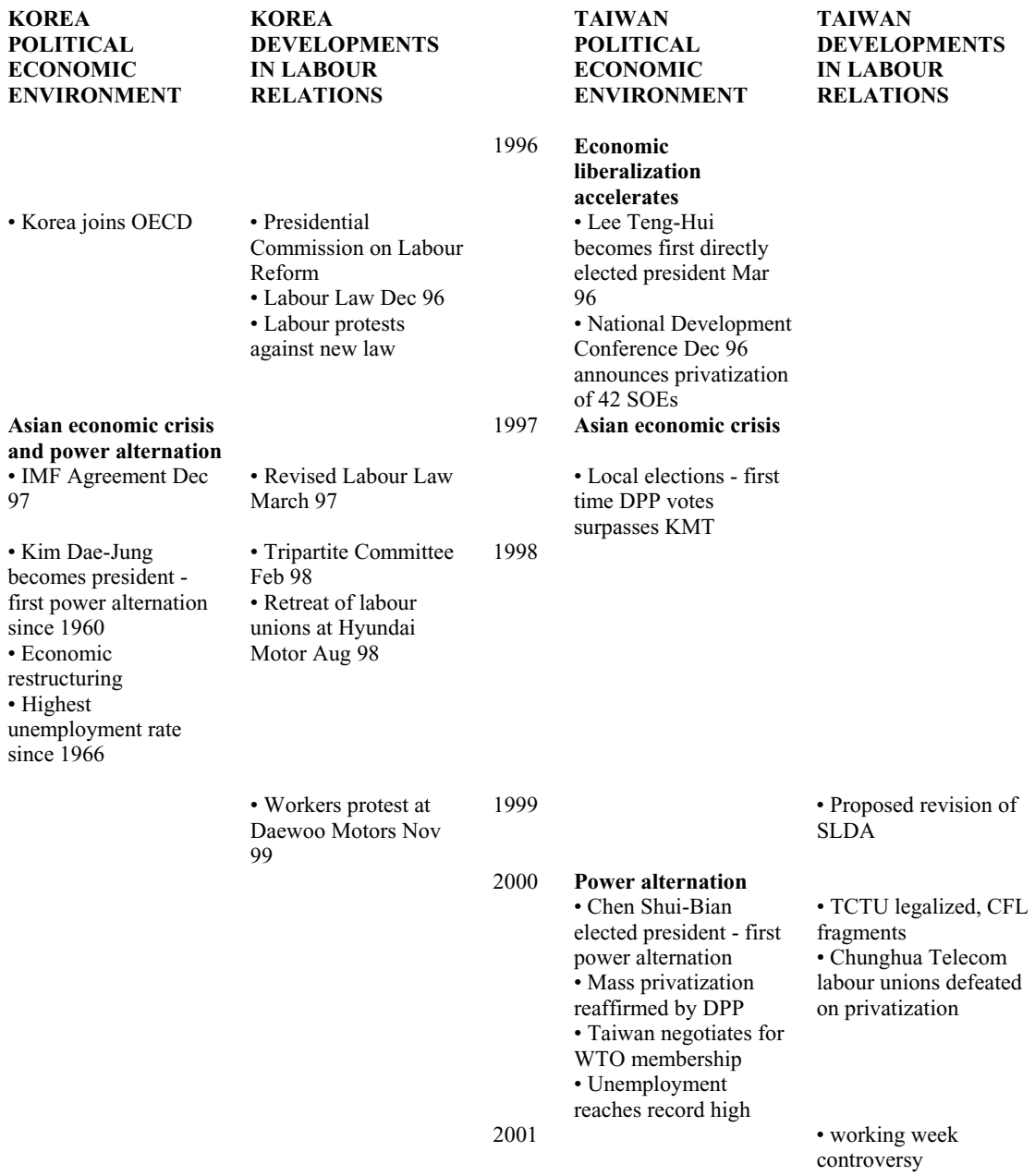

Figure 1. Labour Reform and Its Political-Economic Context in Korea and Taiwan Since Democratization (key turning points indicated in bold type).

within the workplace also dilute labour solidarity. Instead of seeking economic and political advance, the labour unions under neo-liberal globalization are confined to the pursuit of more modest objectives of maintaining their organizational strength and resisting further encroachments on their rights at work. Where it was once seen as an economic partner to business under social-democratic regimes, organized labour is cast as a market 'rigidity' under neo-liberalism.

The course of labour reform in post-authoritarian Korea and Taiwan is summarized in Figure 1. Korea and Taiwan since democratization 
exhibit similarities in the course of political and economic development. In both countries, new democratic governments (with strong authoritarian lineages) pursued policies of economic liberalization while seeking to expand their political support coalitions. Three key turning points in the opportunities and constraints facing labour can be identified: democratic transition in the late 1980 ; the turn towards accelerated liberalization from 1996; and the alternation of power to parties historically sympathetic to the labour cause.

\section{The Northeast Asian Pathway of Labour Transition}

Historically, transitions to neo-liberal models of labour market reform have tended to occur against backgrounds of organized labour weakness resulting from economic crisis and political deactivation. The turn towards labour reform on market principles in Korea and Taiwan differed from the typical pattern associated with neoliberalism in three crucial respects. First, it occurred against a background of mobilization and the strengthening of independent labour organizations rather than their deactivation. Second, in spite of the concerns about the negative impact of labour unions on competitiveness, the empowerment of labour coincided with the maintenance of impressive growth rates through most of the 1990 . Third, support for neo-liberalization was restrained and selective at both the elite and mass levels. Northeast Asia's divergence from the typical pathways of neo-liberalization in the developing world can be explained in terms of these three variables (summarized in Figure 2 below), to which we now turn.

\section{Labour and the Political Environment}

Labour control under neo-liberalism is based on the employer's freedom to hire and fire. The role of labour union influence on the setting of wages and conditions depends on the extent of neoliberalization. Chile under Pinochet (1973-90) was perhaps the most extreme manifestation of neo-liberalization. Denied collective support because their organizations were violently dismantled, workers were literally 'atomized' by the marketization strategy. ${ }^{6}$ By achieving very

\footnotetext{
${ }^{6}$ Paul W. Drake, Labor Movements and Dictatorship: The Southern Cone in Comparative Perspective (Baltimore: Johns Hopkins University Press, 1997), pp. 31-3.
} 


\section{Bureaucratic authoritarian transition to neo- liberalism \\ Recent 'third wave' 'dual transitions' to democracy and economic liberalization}

\begin{tabular}{|c|c|}
\hline $\begin{array}{l}\text { Labour and } \\
\text { political } \\
\text { environment }\end{array}$ & $\begin{array}{l}\text { - Repression and } \\
\text { deactivation of } \\
\text { mobilized labour } \\
\text { movement }\end{array}$ \\
\hline $\begin{array}{l}\text { Economic } \\
\text { performance }\end{array}$ & $\begin{array}{l}\text { - Prolonged crisis, high } \\
\text { unemployment }\end{array}$ \\
\hline \multirow[t]{2}{*}{$\begin{array}{l}\text { Ideological } \\
\text { conditions }\end{array}$} & $\begin{array}{l}\text { - Public disillusionment } \\
\text { with statist economics } \\
\text { and its social settlement }\end{array}$ \\
\hline & $\begin{array}{l}\text { - Strong middle class } \\
\text { and elite hostility to } \\
\text { mobilized labour unions } \\
\text { - Polarization between } \\
\text { pro- and anti-liberals } \\
\text { over the appropriate } \\
\text { policy response }\end{array}$ \\
\hline $\begin{array}{l}\text { Political } \\
\text { economic } \\
\text { outcomes }\end{array}$ & $\begin{array}{l}\text { - Neo-liberal economics } \\
\text { with authoritarian } \\
\text { politics }\end{array}$ \\
\hline
\end{tabular}

Northeast Asian NICs since democratization

- Moderate legal restraints

- Prolonged crisis, high unemployment

- Public disillusionment with statist economics and its social settlement, failure of social pacts.

- Labour unions demoralized by failures of statist economics

- Neo-liberal populism

- Neo-liberal economics with democratic politics
- Residual authoritarian controls under challenge by newly autonomous labour organizations

- Prolonged growth, tight labour markets

- Public expectations for effective state to counteract social and economic failures of the market

- Selective middle class support for labour causes

- Belief in compatibility between free markets and social redistribution: democratic market economy, third way etc.

- Implementation of marketization measures on a selective basis - Economic pluralism versus free for all

Figure 2. Pathways to the Marketization of Labour Relations.

flexible labour markets, labour control in authoritarian Korea and Taiwan approximated the neo-liberal ideal, but in its use of producer organizations for the purposes of manipulation and mobilization, it also resembled the corporatist project. The flexible labour markets of Korea and Taiwan also existed in economic contexts that were highly statist (see below). Moreover, 'flexibility' existed not because the labour market was deregulated, but because the state allowed business to flout protective regulations.

It is widely acknowledged that Korea and Taiwan represent exemplars of gradualism in democratization and economic liberalization. Democratic breakthroughs in both countries occurred in 1987. Korea made a transition to free elections in the space of a year whereas Taiwan did not complete the process until 1996. Democratization in the late 1980 s ushered in a period of labour activation, and 
transformed the conditions under which the later labour market reforms would take place. This is evident from the trends in Tables 1 and 2 showing the escalation in the incidence of labour disputes, workers involved and workdays lost. The economic impact of labour activation is also evident from the upward trend in unit labour costs in the years immediately following democratization (Table 4). Numbers do not tell the whole story. In the case of Taiwan for example, commentators noticed that disputes took on intensive, confrontational characteristics not previously witnessed. Not only did more labour disputes turn into actual strikes, there was an escalation of illegal actions, and labour unions became pro-active in making demands from employers. ${ }^{7}$ Labour protest was one expression of the rising tide of social dissatisfaction. That governments became more responsive to discontent after democratization could be seen from the growth of the social component of public expenditures (Table 5) and redistributional initiatives, and the introduction of new protective labour laws and the amendments of old ones (Figure 1).

Korean labour protest peaked in 1987 (the year of the so-called Great Workers' Struggle). Although the incidence of protests and numbers of workers involved declined significantly thereafter, working days lost (perhaps the clearest indicator of strike action) remained a serious problem for Korean industry (e.g. the post-1987 low of 393 , O00 days compared with the pre-1987 high of 72,000 days in 1985). In Taiwan, democratization was followed by a new peaks in disputes (number of cases, workers involved and workdays lost) in 1989. The incidence of disputes and workers involved fell during 1990-2 but escalated thereafter and reached new peaks in 1995 (numbers of workdays lost), 1998 (total workers involved) and 1999 (total cases of disputes). It is noticeable that the average labour dispute in Taiwan was much smaller than in Korea (workers per dispute). Another interesting comparison is the proportionate amount of lost worktime that reveal a far more serious problem of disruption by labour militancy for Korea. For example, the peak year for work days lost in Taiwan was 1995 (46,926 days in an employed population of 9 million) while the same year represented the lowest year for workdays

\footnotetext{
${ }^{7}$ Archie Kleingartner and Hsueh-Yu Peng (1991) 'Taiwan: An Exploration of Labour Relations in Transition', British Journal of Industrial Relations 29, 3, September (1991), pp. 427-45 at pp. 436-8; Michael Hsin-Huang Hsiao, 'The Labor Movement in Taiwan: A Retrospective and Prospective Look', in Denis Fred Simon and Michael Y.M. Kau, eds, Taiwan: Beyond the Economic Miracle (Armonk, NY: M.E. Sharpe, 1992), pp. $15^{1-67}$.
} 
TABLE 1

Labour Disputes in Korea 1975-1999

\begin{tabular}{|c|c|c|c|c|c|c|c|c|c|}
\hline & \multirow[b]{2}{*}{$\begin{array}{c}\text { Total } \\
\text { disputes } \\
\text { (cases) }\end{array}$} & \multirow[b]{2}{*}{$\begin{array}{l}\text { Workers } \\
\text { involved } \\
(1, \text { ooos })\end{array}$} & \multirow[b]{2}{*}{$\begin{array}{l}\text { Workers } \\
\text { per dispute } \\
\text { (persons) }\end{array}$} & \multirow[b]{2}{*}{$\begin{array}{l}\text { Working } \\
\text { days lost } \\
(1, \text { ooos })\end{array}$} & \multicolumn{5}{|c|}{ Dispute Causes } \\
\hline & & & & & $\begin{array}{c}\text { Wage } \\
\text { Bargaining }\end{array}$ & $\begin{array}{c}\text { Delayed } \\
\text { wages }\end{array}$ & $\begin{array}{c}\text { Unfair } \\
\text { Labour } \\
\text { practice }\end{array}$ & $\begin{array}{c}\text { Better } \\
\text { Labour } \\
\text { conditions }\end{array}$ & Others \\
\hline 1980 & 407 & 49 & 120 & 62 & $3^{8}$ & 287 & - & 14 & 68 \\
\hline 1981 & 186 & 35 & 188 & 31 & $3^{8}$ & 69 & 4 & 32 & 43 \\
\hline 1982 & 88 & 9 & 102 & 12 & 7 & 26 & - & 21 & 34 \\
\hline 1983 & $9^{8}$ & 11 & 112 & 9 & 8 & 35 & - & 19 & $3^{6}$ \\
\hline 1984 & 113 & 16 & $14^{2}$ & 20 & 29 & 39 & 7 & 14 & 24 \\
\hline 1985 & 265 & 29 & 109 & 64 & 84 & 61 & 12 & 47 & 61 \\
\hline 1986 & 276 & 47 & 170 & 72 & 75 & $4^{8}$ & 16 & $4^{8}$ & 89 \\
\hline 1987 & 3,749 & 1,262 & 337 & 6,947 & 2,613 & 45 & 65 & $5^{66}$ & $4^{60}$ \\
\hline 1988 & 1,873 & 293 & $15^{6}$ & 5,401 & $94^{6}$ & 59 & 59 & $13^{6}$ & 673 \\
\hline 1989 & 1,616 & 409 & 253 & $6,35^{1}$ & $74^{2}$ & 59 & 10 & 21 & 784 \\
\hline 1990 & 322 & 134 & $4^{16}$ & 4,487 & 167 & 10 & - & 2 & 143 \\
\hline 1991 & 234 & 175 & 748 & 3,271 & 132 & 5 & - & 2 & 95 \\
\hline 1992 & 235 & 105 & 447 & $1,5^{28}$ & 134 & 27 & - & - & 74 \\
\hline 1993 & 144 & 109 & 757 & 1,308 & 66 & 11 & - & - & 67 \\
\hline 1994 & 121 & 104 & 860 & 1,484 & $5^{1}$ & 6 & - & - & 64 \\
\hline 1995 & 88 & $5^{0}$ & $5^{68}$ & 393 & 33 & - & - & - & 55 \\
\hline $199^{6}$ & 85 & 79 & 929 & 893 & 19 & 1 & - & - & 65 \\
\hline 1997 & 78 & 44 & $5^{64}$ & 445 & 18 & 3 & & & 57 \\
\hline 1998 & 129 & $14^{6}$ & $1,13^{2}$ & $1,45^{2}$ & 28 & 23 & - & - & 78 \\
\hline 1999 & 198 & & & & $4^{O}$ & 22 & - & - & 136 \\
\hline
\end{tabular}


TABLE 2

Labour Disputes in Taiwan 1980-99

\begin{tabular}{|c|c|c|c|c|c|c|c|c|c|c|}
\hline & & & & & Dispute Cau & & & & & \\
\hline & $\begin{array}{l}\text { disputes } \\
\text { by case }\end{array}$ & $\begin{array}{l}\text { disputes } \\
\text { by issue }\end{array}$ & $\begin{array}{l}\text { Labour } \\
\text { contracts }\end{array}$ & Wages & Retirement & $\begin{array}{c}\text { Occupational } \\
\text { hazards }\end{array}$ & $\begin{array}{l}\text { Other } \\
\text { causes }\end{array}$ & $\begin{array}{l}\text { involved } \\
(1, \text { ooos })\end{array}$ & $\begin{array}{l}\text { per dispute } \\
\text { (persons) }\end{array}$ & $\begin{array}{c}\text { days lost } \\
\text { (days) }\end{array}$ \\
\hline 1980 & 626 & & & & & & & 6.3 & 10 & \\
\hline 1981 & 891 & & & & & & & 7.1 & 8 & \\
\hline 1982 & 1,153 & & & & & & & $9 \cdot 5$ & 8 & \\
\hline 1983 & 921 & & & & & & & 12.3 & 13 & \\
\hline 1984 & 907 & & & & & & & 9.1 & 10 & \\
\hline 1985 & 1,443 & & & & & & & $15 \cdot 5$ & 11 & \\
\hline 1986 & 1,485 & & & & & & & 11.3 & 8 & \\
\hline 1987 & 1,609 & & & & & & & $15 \cdot 7$ & 10 & \\
\hline 1988 & 1,314 & $1,3^{14}$ & 278 & 208 & 409 & 163 & $25^{6}$ & 24.2 & 18 & 8,967 \\
\hline 1989 & 1,943 & 1,943 & 710 & 489 & 234 & 206 & 304 & 62.4 & $3^{2}$ & 24,157 \\
\hline 1990 & 1,860 & 1,860 & 788 & 418 & 202 & 191 & 261 & 34.1 & 18 & 828 \\
\hline 1991 & 1,810 & 2,082 & $8_{3} 6$ & 528 & 210 & 233 & 275 & 12.7 & 7 & - \\
\hline 1992 & 1,803 & 2,100 & 848 & 557 & 185 & 224 & 286 & 12.4 & 7 & 13,783 \\
\hline 1993 & 1,878 & 2,191 & $85^{2}$ & 548 & 207 & 234 & $35^{\circ}$ & 37.9 & 20 & - \\
\hline 1994 & 2,061 & $2,35^{1}$ & $93^{1}$ & 643 & 210 & 295 & 272 & 30.9 & 15 & - \\
\hline 1995 & 2,271 & 2,523 & 962 & 761 & 257 & 272 & 271 & $27 \cdot 3$ & 12 & $4^{6,926}$ \\
\hline 1996 & 2,659 & $2,94^{6}$ & 1,271 & 891 & 239 & 262 & 283 & 21.7 & 8 & 2,210 \\
\hline 1997 & 2,600 & 2,795 & 1,172 & 737 & $25^{1}$ & $3^{66}$ & 269 & 81.0 & $3^{1}$ & 1,098 \\
\hline 1998 & $4,13^{8}$ & 4,465 & 1,945 & 1,321 & 306 & 493 & 400 & 103.6 & 25 & 630 \\
\hline 1999 & 5,860 & na & 2,976 & 1,953 & na & $65^{6}$ & & 30.4 & 5 & 1,375 \\
\hline
\end{tabular}

Nb. From 1991, cases of industrial disputes could be officially classified as having more than one cause.

Source: Council of Labor Affairs, Monthly Bulletin of Labor Statistics, several issues. 
TABLE 3

Labour Unionization Levels in Korea and Taiwan $1980-1998$

\begin{tabular}{|c|c|c|c|c|c|c|c|}
\hline & \multicolumn{2}{|c|}{ KOREA } & \multicolumn{2}{|c|}{ TAIWAN } & \multirow[b]{2}{*}{$\begin{array}{c}\text { Industrial } \\
\text { unions } \\
\text { only }(1, \text { oooa })\end{array}$} & \multirow{2}{*}{$\begin{array}{c}\text { Union } \\
\text { membership/ } \\
\text { total } \\
\text { employed (\%) }\end{array}$} & \multirow{2}{*}{$\begin{array}{c}\text { Industrial } \\
\text { unions } \\
\text { only/total } \\
\text { employed (\%) }\end{array}$} \\
\hline & $\begin{array}{l}\text { Union } \\
\text { membership } \\
(1, \text { ooos })\end{array}$ & $\begin{array}{l}\text { Unionization } \\
\text { rate }(\%)\end{array}$ & $\begin{array}{c}\text { Union } \\
\text { membership } \\
(1, \text { ooos })\end{array}$ & $\begin{array}{c}\text { Occupational } \\
\text { unions } \\
(1, \text { ooos })\end{array}$ & & & \\
\hline 1980 & $94^{8}$ & 20.1 & & & & & \\
\hline 1981 & 967 & 19.6 & & & & & \\
\hline 1982 & 984 & 19.1 & & & & & \\
\hline 1983 & 1,010 & 18.1 & & & & & \\
\hline 1984 & 1,011 & 16.8 & & & & & \\
\hline 1985 & 1,004 & $15 \cdot 7$ & & & & & \\
\hline 1986 & 1,036 & 15.5 & 1,724 & & & & \\
\hline 1987 & 1,267 & $17 \cdot 3$ & 2,100 & 1,369 & 704 & 26.2 & 8.8 \\
\hline 1988 & 1,707 & 22.0 & 2,261 & 1,564 & 696 & 27.9 & 8.6 \\
\hline 1989 & 1,932 & $23 \cdot 3$ & 2,420 & 1,722 & 698 & $29 \cdot 3$ & 8.5 \\
\hline 1990 & 1,887 & 21.5 & 2,757 & 2,057 & 699 & $33 \cdot 3$ & 8.4 \\
\hline 1991 & 1,803 & 19.6 & $2,94^{2}$ & 2,249 & 693 & 34.9 & 8.2 \\
\hline 1992 & 1,735 & 18.3 & $3,05^{8}$ & 2,389 & 669 & $35 \cdot 4$ & 7.8 \\
\hline 1993 & 1,667 & 17.2 & 3,172 & $2,5^{21}$ & $65^{1}$ & $3^{6.2}$ & $7 \cdot 4$ \\
\hline 1994 & 1,659 & 16.3 & 3,278 & 2,641 & 637 & $3^{6.7}$ & 7.1 \\
\hline 1995 & 1,615 & 15.2 & 3,136 & 2,537 & 598 & 34.6 & 6.6 \\
\hline 1996 & 1,599 & 14.7 & 3,048 & $2,4^{61}$ & $5^{88}$ & 33.6 & 6.5 \\
\hline 1997 & 1,484 & 13.5 & 2,959 & 2,369 & 590 & 32.2 & 6.4 \\
\hline 1998 & 1,402 & 13.8 & 2,927 & $2,35^{1}$ & 576 & 31.5 & 6.2 \\
\hline
\end{tabular}

Source: Ministry of Labour, Republic of Korea, Yearbook of Labour Statistics, several issues; CLA, Monthly Bulletin, Taiwan Area, Republic of China, several issues. 
TABLE 4

GNP, GNP Per Capita and Manufacturing Unit Labour Costs in Korea and Taiwan I970-2OOI

\begin{tabular}{|c|c|c|c|c|c|c|}
\hline & $\begin{array}{c}\text { GNP per } \\
\text { capita ( } \$ \mathrm{US}) \\
\text { Korea }\end{array}$ & $\begin{array}{c}\text { GNP per } \\
\text { capita (\$US) } \\
\text { Taiwan }\end{array}$ & $\begin{array}{l}\text { GNP growth } \\
\text { rate (\% pa) } \\
\text { Korea }\end{array}$ & $\begin{array}{l}\text { GNP growth } \\
\text { rate (\% pa) } \\
\text { Taiwan }\end{array}$ & $\begin{array}{c}\text { Index of } \\
\text { ULC (\$US) } \\
\text { Korea }\end{array}$ & $\begin{array}{c}\text { Index of } \\
\text { ULC (\$US) } \\
\text { Taiwan }\end{array}$ \\
\hline 1980 & $1,5^{89}$ & 2,344 & $\begin{array}{c}7.9 \\
(1971-80)\end{array}$ & $\begin{array}{c}9 \cdot 7 \\
(1970-80)\end{array}$ & na & $43 \cdot 4$ \\
\hline 1985 & 2,047 & 3,297 & $\begin{array}{c}7 \cdot 5 \\
(1980-85)\end{array}$ & $\begin{array}{c}7.1 \\
(1980-85)\end{array}$ & $55^{.0}$ & $5^{1 \cdot 3}$ \\
\hline 1986 & 2,296 & 3,993 & 12.5 & 11.6 & 53.0 & $55 \cdot 6$ \\
\hline 1987 & 3,218 & 5,298 & 12.3 & 12.7 & 60.6 & 66.3 \\
\hline 1988 & 4,295 & 6,379 & 12.0 & 7.8 & 77.8 & $75 \cdot 5$ \\
\hline 1989 & 5,210 & 7,626 & 6.9 & 8.2 & 91.6 & 85.2 \\
\hline 1990 & 5,883 & 8,111 & 9.6 & $5 \cdot 4$ & 93.0 & $89 \cdot 7$ \\
\hline 1991 & 6,757 & 8.982 & 9.1 & 7.6 & 100.3 & 91.1 \\
\hline 1992 & 6,988 & $10,5^{06}$ & $5 \cdot 0$ & $7 \cdot 5$ & 100.0 & 100.0 \\
\hline 1993 & 7,484 & $10,95^{6}$ & 5.8 & 7.0 & 102.7 & 98.1 \\
\hline 1994 & 8,467 & $11,78_{1}$ & 8.4 & 7.1 & 106.8 & 99.0 \\
\hline 1995 & 10,037 & 12,653 & 8.7 & 6.4 & $124 \cdot 3$ & 99.2 \\
\hline 1996 & 10,543 & 13,225 & 6.8 & 6.1 & 125.9 & $95 \cdot 4$ \\
\hline 1997 & $9,5^{11}$ & 13,559 & $5 \cdot 0$ & 6.7 & 100.2 & 89.5 \\
\hline 1998 & $6,75^{\circ}$ & 12,333 & -6.7 & 4.6 & $6_{5} .8$ & $77 \cdot 4$ \\
\hline 1999 & $8,55^{1}$ & 13,248 & 10.9 & $5 \cdot 7$ & 68.8 & 78.3 \\
\hline 2000 & 9,628 & 14,188 & $9 \cdot 3$ & $5 \cdot 9$ & 70.2 & 78.1 \\
\hline 2001 & 8,900 & $12,94^{1}$ & 3.0 & -1.9 & 64.7 & $69 \cdot 4$ \\
\hline
\end{tabular}

Source: National Statistical Office, Major Statistics of Korean Economy, several issues; Directorate General of Budget, Accounting and Statistics, Republic of China, Statistical Yearbook of the Republic of China, several issues, Department of Labour (US), Foreign Labour Statistics (www.bls.gov/fls/home.htm).

lost in post-1987 Korea (393,ooo in an employed population of 20.8 million).

Korean and Taiwanese labour used the democratic opening to advance their membership base (Table 3). In Korea, the unionization rate peaked at 23.3 per cent in 1989 and went into decline thereafter. There was rapid growth in Taiwan's unionization rate during the late 1980 s. As a proportion of the total employed, union membership accounted for 36.7 per cent in 1994. Such a figure however, gives an inflated picture of labour's organizational strength. The growth of labour unionization in Taiwan was exaggerated by the rise of occupational unionism (as opposed to workplace based industrial unionism). Membership of occupational or craft unions was a channel through which predominantly self-employed workers (e.g. taxi drivers) could gain access to state benefits like health insurance. In reality, the development of such unions tended to dilute labour's 
collective identity. Their numerical preponderance strengthened the representation of the politically apathetic against those seeking to bolster labour's autonomy from the state. If the membership of occupational unions is excluded, then the 'true' rate of unionization (i.e. of industrial unions only) in Taiwan was considerably lower than in Korea.

In spite of defeats and membership declines from the late 1980 , organized labour made some permanent gains in its political position. Democratization afforded the opportunity for labour unions to develop their national centres or federations. Through such centres, labour could coordinate national level actions. National labour centres also helped to promote labour autonomy by countering the tendency of managements to dominate company labour unions (the basic level of union structure inherited from authoritarianism). Authoritarianism had compelled all labour unions to affiliate with one officially-licenced national labour organization, the Federation of Korean Trade Unions in Korea and Chinese Federation of Labour in Taiwan. ${ }^{8}$ In Korea, unofficial activists had vigorously challenged the authority of company labour representatives since the late 1970 s. $^{9}$ After democratization, the representational monopoly of the FKTU was challenged by the emergence of a rival militant national centre, the National Council of Trade Unions, composed of unions newly organised since 1987 . The militancy of the rival federation alienated important middle class opinion and triggered the crackdown by the Roh regime in 1991. But its active stance (not to mention grassroots opinion) also forced the state-sponsored FKTU into taking a more independent and critical line. Sobered by the failures of its past militancy and with its internecine disputes over, the NCTU was relaunched as the Korea Confederation of Trade Unions in 1995. That the KCTU was accorded equal representation with the FKTU on important national deliberation panels (e.g. Presidential Commission on Labour Reform in 1996 and the Tripartite Committee in 1998), even though it was

${ }^{8}$ The FKTU was established in 1946 as a right-wing instrument against the leftist unions that were then in the ascendancy. It was reorganized in 1961 by the military junta. The CFL was first formed on the mainland in 1928 and reorganized when the KMT retreated to Taiwan in $195^{\circ}$. Whereas the FKTU was the creation firstly of a charismatic dictator and then of the military junta, the CFL was the extension of the one party regime. Its unshifting allegiance to the KMT would therefore last as long as the KMT retained state power.

${ }_{9}^{9}$ Asia Monitor Resource Centre, Min Ju No Jo: South Korea's New Unions (Hong Kong: Asia Monitor Resource Centre, 1987), pp. 42-5o. 
formally illegal, was indicative of the following it had built up. Both the FKTU and the KGTU coordinated the mass strikes in response to the December 1996 labour legislation. As of 1999, the KCTU claimed 573 , ooo members (out of a total of 1.49 million labour union members officially listed for that year).

Taiwanese labour unions have faced similar obstacles in the development of an independent national federation. The CFL, like the FKTU has remained attached to state funding. But unlike its Korean counterpart, the CFL failed to assert a more independent line from the ruling KMT (e.g. its board chairman was elected to the KMT's Central Standing Committee in 1997). The CFL's linkage with the KMT party-state was stronger than the FKTU allegiance to the Korean regime. The GFL-KMT linkage persisted despite the emergence of more militant and independent labour leaders at the industrial and local levels. As in Korea, within Taiwan's democratic regime, the Labour Union Law allowed for only one national federation to exist. The formation of the TCTU was declared in 1998 with a membership of 300,000 industrial union members (i.e. over half of that category). It was, however, not until the KMT's loss of the presidency in 2000 that the CFL separated itself from the party and the rival Taiwan Confederation of Trade Unions was able to gain legal recognition.

Labour unions also bolstered their organizational strength and influence from their political interactions. Under authoritarianism, independent political activity by labour unions was strictly proscribed in the name of national security. The role of labour organizations was to mobilize worker enthusiasm behind the regime's political and economic goals. Democratization gave labour unions the opportunity to initiate their own political agendas. The mobilization potential of labour unions also made them potentially attractive allies to politicians and parties. In spite of severe institutional restraints, ties between labour and opposition politicians and activists were first established during the era of united opposition to authoritarianism. The main opposition leader in Korea, Kim Dae-Jung, had been supporting fairer distribution ever since 1971 . In place of labour repression, Kim argued for a more inclusive approach under the slogan of 'democratic market economy'. ${ }^{10}$ Many labour activists supported Kim as the most progressive of the conservative mainstream politicians. A factor

${ }^{10}$ Dae-Jung Kim, Mass Participatory Economy: A Democratic Alternative for Korea (Cambridge, Mass.: Harvard University-University Press of America, 1995) and DJnomics: A New Foundation for the Korean Economy (1999) (www.democracy-market.org). 
preventing labour from uniting behind Kim was the regional factor in Korean politics, a factor which outweighed ideological considerations at election times. For Kim, pan-regional electoral coalitions could be forged by appealing to labour. Being the political boss of the smaller region, he could not capture the presidency on the basis of regional appeal alone. In both countries, support for labour became one component of the oppositional platform but it did not become the dominant component.

The labour movement in Taiwan has also fostered mutually beneficial relations with the main opposition party. Taiwan's main opposition party, the pro-independence DPP, was looking to expand its electoral base and sought labour support. By the early 1990s, its appeal on the basis of Taiwanese identity and independence was reaching its limits. Labour was attracted to the DPP, factions of which (notably New Tide) held strong pro-labour sympathies. Also attractive was the DPP's success at capturing local government power. Under Taiwan's decentralized administrative system, DPP control of local administrations delivered material advantages to the labour unions and was a spur to the formation of union organizations. ${ }^{11}$ Access to local political power and resources compensated for the continuing dominance of the central CFL by the KMT party-state. Some DPP legislators actively supported the campaign to legalize the TCTU. ${ }^{12}$ In refusing to legalize the rival TCTU, the ruling KMT correctly calculated that it could not count on the support of the new federation. The ban in turn reinforced the TCTU's support for the opposition DPP (which made legalization a plank of its electoral platform in the 2000 presidential contest).

That organized labour's political influence had its limits in Korea and Taiwan was evident from the failure of labour based political parties. In Taiwan, some pro-labour sections of the opposition DPP and other activists launched the moderately socialist Labour Party in 1987 and then the more openly leftist Workers' Party in 1989 . Korean socialist parties proved equally fractious and unpopular (e.g. the People's Party got less than one per cent of the vote in the 1992 legislative election). The attempt to translate labour activism into electoral support encountered formidable obstacles. Being identified as 'left-wing' was a serious political liability in

${ }^{11}$ Huang, 'Learning the New Game', pp. 8-10.

12 'Quanchangong zhengqu hefahua' [TCTU seeks legalization], Ziyou Shibao [Freedom Times], (20 October 1998). 
societies where socialism had only recently been harshly proscribed. Unionized workers continued to represent a relatively privileged minority of the labour force working for public monopolies or private oligopolies. In Taiwan, the rapid union membership expansion led to the preponderance of those who were politically apathetic and primarily interested in access to state benefits. Politically, labour's political participation was hindered by the remnants of authoritarian legislation. For example, Korean public sector workers (including teachers) were prohibited from joining labour unions and the labour unions themselves were prohibited from making financial donations to political parties. Given that existing opposition parties were already well established, and embraced the labour issue to some extent, it made sense for labour unions to advance their cause by association with those parties. More successful has been the formation of labour support groups by new middle class activists (academics, journalists, students) like the Citizens Coalition for Economic Justice in Korea. ${ }^{13}$ and the Taiwan Labour Front (some of whose activists would become advisers in the labour ministry under the DPP). Relying on well researched arguments and peaceful tactics that win over public opinion, the activities of these groups complemented the labour unions' more direct tactics and gave respectabiity to the labour cause.

\section{Economic and Ideological Conditions}

Marketization strategies do not usually require extreme authoritarian concomitants of type seen in countries like Chile. In the right economic and ideological context, moderate legal restraints tend to suffice. Radical pro-market reforms are typically introduced in response to economic crises when organized labour resistance is demoralized by high unemployment and the absence of viable alternatives. In Latin American countries like Argentina and Brazil, the failure of the heterodox stabilization programmes of the late 1980 os marked the last gasp of the populist-statist alternative to neo-liberalism. Korea took a bold step towards the liberalization of labour markets in early 1998 when the economy was suffering its worst crisis in 40 years. Escaping relatively lightly from the 1997 Asian crisis, Taiwan's economy nevertheless experienced a slowdown. In both Korea and Taiwan, the

${ }^{13}$ Su-Hoon Lee (1993) 'Transitional Politics of Korea, 1987-1992: Activation of Civil Society', Pacific Affairs, 66, 3 (1993) pp. $35^{1-67}$, pp. $363-5$. 
debate about the merits of labour market reform intensified during the mid-1990s as concerns grew about the loss of competitiveness (as demonstrated by the flight of manufacturing investment to continental Asia). But neither Korea nor Taiwan experienced the kind of prolonged economic and ideological crises associated with the introduction of neo-liberal programmes elsewhere. As Tables 4 and 5 indicate, despite the slowdown of growth by historical standards (a sign of industrial maturity), the macroeconomic context right up to the 1997 crisis was one of robust growth with tight labour markets.

Economic crises generate ideological pressures to rethink development strategies. Generally speaking, the deeper the crisis of statist economics, the more converts are won over to neo-liberal alternatives, and the poorer the economy, the higher the stakes attached to economic policy change. The ideological crisis can produce polarization at both elite and mass levels between the supporters of the economic status quo and the neo-liberal alternative. Under such circumstances, the neo-liberal recovery programme can only be initiated with the application of considerable force against its opponents. The authoritarian neo-liberal experiments of Chile and Argentina during the 1970 are examples of this pattern of transition. But more recent experiences from Latin America and Eastern Europe show that a neo-liberal resolution of the ideological crisis can follow a democratic sequence. In such a scenario, mass discontent with the failures of statism forces economic policy shift in a radical neo-liberal direction. In such a situation of 'neo-liberal populism', even those who stand to lose out from neo-liberal reform programmes support the policy change. ${ }^{14}$ By contrast, the background of growth meant that Korea and Taiwan were not faced with such absolute choices about economic policy reform. That Korea and Taiwan did not approach the patterns of ideological crisis resembling those described above can be seen from the nature of the debate about labour market reform in the policy community.

The new democratic regimes of Korea and Taiwan were undoubtedly pro-business regimes that accepted the principle of economic liberalization. The economic liberalization cautiously started by authoritarian regimes in the early 1980 s was continued by their democratic successors. In Korea, the arrival of a reformist president in the shape of Kim Young-Sam in 1993 gave fresh impetus to reform. Using the

${ }^{14}$ For example, Kurt Weyland, 'Neoliberal Populism in Latin America and Eastern Europe', Comparative Politics, 31 (1999), pp. 379-401. 
term 'globalization' to characterize his government's policy direction, Kim was eager to leave his historical mark as the leader responsible for completing Korea's democratization and economic liberalization. Under his leadership, Korea joined the WTO (1995) and the OECD (1996). Liberalization was seen as the answer to the erosion of national competitiveness caused by the 'high cost, low efficiency' economic structure. The over-regulated labour market was identified as one source of these 'costs' (together with land, transport and interest rates). From 1996, reform of the labour market and the institutional basis of labour relations was accorded high priority with the establishment of a Presidential Commission on Labour Reform. For Taiwanese labour unions, 1996 was also a significant year. Having obtained a direct electoral mandate that year, the KMT accelerated the introduction of the market approach in response to concerns about declining competitiveness (symptoms of which were the outflow of investment to continental Asia and the recruitment of migrant labour). For example, the National Development Conference initiated the programme for the privatization of 42 SOEs (the most unionized sector of the economy) in five years.

Part of a wider pro-liberalization campaign, business circles in Korea and Taiwan called for the repeal of protective labour legislation which they deemed to be institutional impediments to the efficient working of the labour market. Ironically, most of these laws were passed by authoritarian regimes (Figure 1). In the post-authoritarian labour environment, the constraints that previously made labour flexible were being undermined. Protective labour laws that previously could be disregarded now had to be observed. The Federation of Korean Industries (the peak organization of the top 30 business conglomerates or chaebol) complained about the slow pace of deregulation and challenged the government to allow market forces to enter the 'sacred precincts' of the economy like finance and $\mathrm{SOEs}^{15}$ while the Korea Employers' Federation (KEF) argued that excessive wage increases were eroding national competitiveness. For example, KEF used data showing Korean manufacturing wages to be very high at the \$10,00o GNP per capita level compared with other economies at the

${ }^{15}$ Il-Joong Kim, 'The Results and Future Course of Korea's Deregulation Policy', in Il-Joong Kim, ed., The Role of the Three Branches of Government for the Rule of Law and the Free Market in Korea (Seoul: Korea Economic Research Institute, 1995), pp. 169-204, at p. 191. 
corresponding stage of development. ${ }^{16}$ Emphasizing the detrimental effects of high labour costs on competitiveness, Taiwan's business community lobbied for the revision of the Labour Standards Law of $1984 \cdot{ }^{17}$

Influential though it was, the business perspective did not achieve the kind of intellectual dominance in Korea and Taiwan that it did elsewhere. Critics, especially in Korea, countered the main business claims about the harmful economic effects of allegedly over-regulated labour markets. Korean labour think-tanks held business responsible for raising production cost through under-investment in facility and involvement in speculative activities. ${ }^{18}$ Critics (and mainstream commentators) viewed business' emphasis on minimizing local labour costs (e.g. constantly comparing them with unmatchably low labour cost in mainland China) as indicative of a regressive mentality that failed to see labour an asset to be developed through investment. ${ }^{19}$ Data in Table 4 showing falling ULCs in Korea and an annual increase of only two per cent for Taiwan between 1985 and 1999 lend support to this view. The relevance of Japanese and European alternatives to neoliberal employment systems were emphasized by Korean, Taiwanese

${ }^{16}$ Korean Employers Federation, Industrial Relations and the Labour Market in Korea I996 (Seoul: Korea Employers' Federation 1996), p. 34.

17 Yin-Wah Chu (1996) 'Democracy and Organized Labor in Taiwan: The 1996 Transition', Asian Survey 36, 5 (1996) pp. $495^{-5^{10}}$, especially pp. $5^{\mathrm{o}}-8,5^{\text {o9-10. }}$

${ }^{18}$ For example, Soo-Bong Uh, International Competitiveness in Trade and Investment: Challenges and Opportunities for Trade Unions. The Case of Korea (Seoul: Research Centre of the FKTU, 1995) p. $5^{2}$.

${ }^{19}$ Ronald A. Rogers, 'The Role of Industrial Relations in Recent National and Enterprise Level Industrial Strategies in the Republic of Korea', in Lawrence Krause and Fun-Koo Park, eds, Social Issues in Korea: Korean and American Perspectives, (Seoul: KDI Press, 1993), pp. 67-108, at p. 77; Thomas A. Kochan, 'Industrial Relations and Human Resource Policy in Korea: Options for Continued Reform' in Lee-Jay Cho and Yoon-Hyung Kim, eds, Korea's Political Economy: An Institutional Perspective (Boulder: Westview Press 1994) pp. 663-97, at pp. 679-82; Takeshi Inagami, 'Labour Market Policies in Asian Countries: Diversity and Similarity Among Singapore, Malaysia, the Republic of Korea and Japan', ILO Employment and Training Papers, 34, (1998) pp. 52-3; Mao-Xing Zeng 'Guanchang wenti jingyan tan' [Discussion on the experience of the problem of plant closure] Paper delivered at the TCTU National Conference, Kaohsiung. (29-3o September 1999); Taipei Times, 'Labour is a Crucial Factor to Industry' (8 December 2000). Inagami argues that whereas the Japanese model prioritizes the investment in the development of employee skills (with its connotations of cooperation and long term employment stability), Korean management sees the import of superior technology as the path to productivity growth (despite the official government emphasis on training). 
and foreign commentators. These included functional flexibility ${ }^{20}$ labour participation in decision-making ${ }^{21}$ and societal corporatism. ${ }^{22}$

Faced with a more active labour movement and influenced by visions of societal corporatism advocated by influential commentators, the Korean state's strategy towards labour was more explicitly inclusionary. The Kim Young-Sam government used the term 'social consensus'. In seeking to bridge the deep labour-business divide, tripartite structures of societal corporatism had been advocated and experimented with since 1991 (when the first tripartite roundtable was convened). Even the ill-fated labour reform of December 1996 contained provisions for the extension of labour's legal rights (to be granted in exchange for labour's acceptance of labour market flexibility reforms). Facing a weaker labour movement, Taiwan's KMT regime was less receptive to notions of tripartism. In 1999, it planned new restrictions (e.g. bans on strikes in key industries, mandatory cooling off, ending of compulsory arbitration) through revision of the 1988 Settlement of Labour Disputes Act. These proposals were

${ }^{20}$ Where 'functional flexibility' denotes labour mobility within a firm (in which labour is guaranteed some degree of security) while 'numerical flexibility' denotes ease of hire and fire. The former entails long term worker commitment to the firm (hence greater security of employment) and was said to be more suitable to Korea's work traditions. See Johngseok Bae et al., 'Korean Industrial Relations at the Crossroads: The Recent Labour Troubles', Asia Pacific Business Review, Spring (1997), pp. 148-6o, pp. $155^{-7}$.

21 Shi-Rong Wang, 'Laogong zhengce yu qiye fazhan' [Labour policy and enterprise development], Paper at the Conference on Government-Enterprise Relations (Taipei: National Chengchi University, April 1988); Zhi-Xiang Han, 'Laodong canyu ji zuzhi huanjing' [Labour Participation and Organizational Environment] in Council of Labour Affairs, ed., Jiaru shijie maoyi zuzhi dui laodong shichang de chongji yu yinying zhengce: lunwen ji [Impact of WTO Entry on the Labour Market and the Appropriate Policy Response: A Discussion Paper] (Taipei: CLA, 1997) pp. 197-235; Zhi-Yue Cheng (2000) 'Laozi guanxi tixi minzhuhua de yiyi yu fangxiang' [The Meaning and Future of the Democratic Industrial Relations System], in Yun-Han Chu and Tzong-Ho Bau, eds, Minzhu zhuanxing yu jingji chongtu: jiushi niandai taiwan jingji fazhan de kunjing yu tiaozhan [Democratic Transition and Economic Conflict: Problems and Challenges of Taiwan's Economic Development in the 1990s] (Taipei: Laureate Book Co., 200o) pp. $155^{-80 .}$

22 Presidential Commission on Economic Restructuring, Realigning National Priorities for Economic Advance: Presidential Report on Economic Restructuring (Seoul: 1988), pp. 101-48; David Lindauer, and Ezra Vogel, 'Toward a Social Compact for Korean Labour', Harvard Institute for International Development Discussion Paper 317 (1989); Keun Lee and Chung H. Lee (1992) 'Sustaining Economic Development in South Korea: Lessons from Japan', Pacific Review, 5, 1 (1992), pp. 13-24; Rogers, 'The Role of Industrial Relations'; Chalmers Johnson, 'What is the Best System of National Economic Management for Korea?', in Cho and Kim, eds, Korea's Political Economy, pp. $63-85$, at p. 82 . 
overtaken by the 2000 presidential election campaign (during which the KMT candidate took a conciliatory attitude on the labour issue).

That the democratic regimes of Korea and Taiwan were following courses that were pro-business rather than neo-liberal could also be seen from the overall context of development strategy in which liberalizing reform occurred. While responding to local and foreign demands for financial liberalization, the governments of Korea and Taiwan continued to limit foreign capital inflows (long term flows in Korea, short term ones in Taiwan) New developmentalist measures were introduced alongside liberalizing ones. In place of the policy loan, the Korean and Taiwanese governments initiated functional industrial supports and took the lead in areas where private initiative was thought to be lacking. ${ }^{23}$ Apart from the introduction of new forms of 'market conforming' intervention, economic liberalization also coincided with the growth of the state's social expenditure (Table 5).

Although the driving force behind the improvement of living standards during the era of authoritarian developmentalism was employment generation, the state was not immune from taking redistributional and welfare initiatives. As is well known, the developmental states were built on successful land reforms of

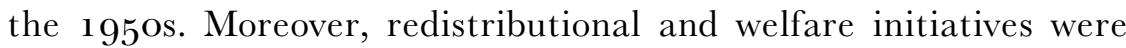
consistent with the paternalistic ideologies and security concerns of the ruling KMT in Taiwan and the military in Korea. Such measures were being stepped up even before the democratic opening as the state sought to pre-empt social protest by acknowledging the problem of relative inequality. In Taiwan, these included the Labour Standards Law of 1984 and the creation of the Council of Labour Affairs for the enforcement of the LSL in 1987 (labour issues had previously been a security matter under the Ministry of the Interior). In Korea, the fifth (1981-6) and sixth economic plans (1977-91) stressed social development while a minimum wage law was passed in 1986. After democratization, welfarist policies were extended in response to higher public expectations. For example, Korea's Employment Insurance Law of 1993 created the basis of

${ }^{23}$ Yun-Han Chu, 'The East Asian NICs: A State-Led Path to the Developed World', in Barbara Stallings, ed., Global Change, Global Response: The New International Context of Development (Cambridge: Cambridge University Press 1995), pp. 199-237; Heather Smith, 'Taiwan's Industrial Policy in the 1980s', Asian Economic Journal, 1 1, 1, (1997), pp. $407-41$. 
TABLE 5

Unemployment and Social Expenditure in Korea and Taiwan 1970-2000

\begin{tabular}{|c|c|c|c|c|}
\hline & \multicolumn{2}{|c|}{ Rate of Unemployment } & \multicolumn{2}{|c|}{ Social expenditure/public expenditure } \\
\hline & KOREA (\%) & TAIWAN (\%) & KOREA (\%) & TAIWAN (\%) \\
\hline 1970 & 4.5 & 1.7 & & \\
\hline 1975 & 4.1 & 2.4 & & \\
\hline 1980 & $5 \cdot 2$ & 1.2 & 6.4 & \\
\hline 1985 & 4.0 & 2.9 & 6.8 & 6.3 \\
\hline 1986 & 3.8 & 2.7 & $7 \cdot 9$ & 6.6 \\
\hline 1987 & 3.1 & 2.0 & 8.2 & 5.8 \\
\hline 1988 & 2.5 & 1.7 & 7.8 & 7.6 \\
\hline 1989 & 2.6 & 1.6 & 8.9 & $5 \cdot 4$ \\
\hline 1990 & 2.4 & 1.7 & 8.9 & 8.8 \\
\hline 1991 & 2.3 & 1.5 & 10.2 & 9.8 \\
\hline 1992 & 2.4 & 1.5 & $9 \cdot 7$ & 8.6 \\
\hline 1993 & 2.8 & 1.5 & $9 \cdot 2$ & 8.3 \\
\hline 1994 & 2.4 & 1.6 & 9.0 & 8.7 \\
\hline 1995 & 2.0 & 1.8 & 8.1 & 12.1 \\
\hline 1996 & 2.0 & 2.6 & 8.6 & $15 \cdot 7$ \\
\hline 1997 & 2.6 & 2.7 & 9.2 & $15 \cdot 7$ \\
\hline 1998 & 6.8 & 2.7 & 9.8 & 14.2 \\
\hline 1999 & 6.3 & 2.9 & 11.4 & 13.7 \\
\hline 2000 & 4.1 & 3.2 & 11.9 & 16.9 \\
\hline
\end{tabular}

Source: NSO, Major Statistics, several issues; DGBAS, Statistical Yearbook, several issues.

a social welfare system while the ruling KMT regime in Taiwan extended the health insurance system beyond government employees in 1995. In effect, while expanding the role of the market, the state was simultaneously promoting counter measures against market failure.

Support for a version of reform that would counter-balance liberalization with enhanced legal and social protections for labour also extended to the opposition parties. Both Kim Dae-Jung in Korea and Taiwan's DPP were strongly committed to market economics. In power, Kim accelerated the economic liberalization programme. Having expressed his preference for delaying privatization during the election, ${ }^{24}$ President Chen and his new DPP government soon renewed the KMT's privatization policies. Where the KMT saw privatization as a means of building regime support by creating popular capitalism

24 'Quanguo chanzhonggong ban zhengjianhui: wu zu housuanren geshu jijian' [TCTU Holds Political Forum: Five Candidates Voice Their Opinions], Gongshang Shibao [Commerical Times] (1 March 2000). 
and of transferring lucrative assets to business allies, ${ }^{25}$ the DPP viewed it equally approvingly from the perspective of taking the KMT partystate influence out of the economy (e.g. by ending the susceptibility of state employees to KMT electoral pressure).

Such a stance was not merely born of political calculation. Nor was it as contradictory with their pro-labour records as first appeared. It reflected a vision of economic pluralism in which competitive markets and social objectives could be reconciled. In the years of opposition, the focus of the main opposition critique was not market capitalism per $s e$, but rather the bureaucratic authoritarian form of capitalism. From this perspective, a market economy with the proper regulation and social counter-balances (as provided by a legalized labour movement and well developed civic groups) would represent an advance towards economic pluralism rather than regression as would be perceived from the traditional socialist or statist-populist standpoints. Korea's underreliance on market forces was a point repeatedly made by Kim Dae-Jung during his years of opposition. In his vision of 'democratic market economy', he argued that economic decisions should be based on market criteria while the extension of opportunities for labour unions, small and medium industry (SMI), TNGs would reduce of power of the traditionally powerful conglomerate-state alliance. Similarly, in Taiwan, the DPP was selectively pro-labour but not anti-business. It had always had close links with the small entrepreneurs discontented with the pro-SOE, pro-party owned enterprise, pro-heavy industry bias of the KMT regime. In the attempt to shed its anti-business image, the DPP established regular contacts with some of Taiwan's top industrialists in the run up the 2000 election. ${ }^{26}$ President Chen Shui-Bian has even characterized his political philosophy in terms of a social market 'third way'. ${ }^{27}$

At the level of mass opinion, there was neither ideological polarization between the supporters of neo-liberalism and statist economics, nor the 'neo-liberal populism' born of disillusionment with the failures of statism. While supporting economic liberalization (with

${ }^{25}$ Huai-Nan Zu, 'Gongying shiye minyinghua wenti tantao' [An Investigation into the Privatization Issue], Paper delivered at the TCTU National Conference, Kaohsiung, (29-30 September 1999).

${ }^{26}$ These included the leaders of business groups such as Evergreen, Formosa Plastics, China Chemical and China Petroleum. See Shelley Rigger, DPP 20oo, (2000) (http://maple.he.net/ dpp2ooo/platform.htm).

${ }^{27}$ Chen Shui-Bian The Third Way of Taiwan: A New Political Perspective. Lecture at the London School of Economics, University of London (6 December 1999). 
its benefits of consumer choice and opportunities for accumulation), public opinion in Korea and Taiwan also expected the state to continue to perform an effective economic and social role. Whereas middle class opinion swung in favour of neo-liberalism in Latin America, it was more moderate in Korea and Taiwan. The middle classes' support for labour fluctuated according to their perception of the justness of the labour cause. In Korea, the middle classes sympathized with labour strikes in the immediate aftermath of democratization but then supported the anti-labour crackdown in 1991 when militancy was seen to be damaging the national economy. This has been interpreted as evidence of the divergence of interests between the middle and working classes after the unifying objective of democratization had been achieved. ${ }^{28}$ But the strong middle class support (especially from white-collar workers in industries like broadcasting) for the labour protest against the Kim Young-Sam government's labour laws in early $1997^{29}$ suggests such a view to be too pessimistic. Similarly in Taiwan, middle classes have supported the labour causes perceived to be reasonable (protests in the aftermath of democratization, in the demands for the reduction of the working week) but opposed those demands that appeared to be excessive (such as the Chunghua Telecom workers' demands for job security and substantial privatization benefits in summer 2000). The proliferation of pro-redistributional civic groups consisting largely of middle class activists is another indicator of the potential for correspondence between middle class and organized labour interests. And in both countries, corruption cases and avoidable disasters (like collapsing buildings) regularly remind the middle classes of the social failings of unaccountable capitalism.

The mixed results for the labour unions since the alternation of power lend support to the above analysis. Both President Kim DaeJung and President Chen Shui-Bian's party, the DPP, were known for their sympathy to labour and other politically excluded constituencies. Thus the DPP victory appeared to herald a major pro-labour shift. ${ }^{30}$

${ }^{28}$ Joo-hee Lee, 'Class structure and Class Consciousness in South Korea', Journal of Contemporary Asia, 27, 2 (1997), pp. 135-55.

${ }^{29}$ Barry K. Gills and Dong-Sook S. Gills (2000) 'Globalization and Strategic Choice in South Korea: Economic Reform and Labour', in Samuel K. Kim, ed., Korea's Globalization (New York: Cambridge University Press, 2000), 29-53, at p. 42.

${ }^{30}$ Taipei Times, 'Government should be firm with Chunghua', (25 August 200o); Zhongguo Shibao [China Times] 'Laogong zhengce kaishi xiang laofang qingxiang' [Labour Policy Begins to Tilt Towards Labour] (16 June 2000). 
For the labour unions, the institutional environment has been altered as a result. The radical rival labour federation, the TCTU was finally legalized in May 2000. Activists with pro-labour sympathies also came to be located in advisory roles in key ministries, including the CLA. ${ }^{31}$ In Korea, the Kim Dae-Jung regime inherited a bad crisis. Unable to compromise when economic conditions were favourable, the representatives of labour and business belatedly agreed to join a social pact for recovery (Tripartite Committee). This was the first such arrangement in industrializing Asia and broke with Korea's history of intensified labour repression during economic downturns. Labour gained institutional reforms including the legalization of the radical KCTU, the right to multiple unions and third party involvement in disputes, and partial union rights for key public sector workers. President Kim also appointed a number of former social activists as his advisers. ${ }^{32}$

Yet the limits of labour influence on the new governments are also very apparent. While granting labour new political rights and some social measures, ${ }^{33}$ both governments have continued the marketization strategies begun by their predecessors. For example, the DPP government in Taiwan is continuing with the privatization programme initiated by the KMT and stood firm when challenged by the well organized Chunghua Telecom labour unions. In Korea, while introducing new labour rights and social welfare reforms, the Kim Dae-Jung government nevertheless persisted with the painful restructuring and liberalization reforms mandated by the IMF. These include implementation of the March 1997 labour reforms resisted by the labour unions, liquidation of hopeless enterprises, privatization and the sale of cash strapped enterprises to foreign buyers.

${ }^{31}$ For example, Prof. Jason Chin-Hsin Liu, formerly of the Taiwan Labour Front.

${ }^{32}$ For example, Prof.Jin-Soon Lee, formerly of the Citizen's Coalition for Economic Justice.

${ }^{33}$ In Taiwan, the attempt by the DPP government to pass legislation for a shorter working week has been bogged down by the inter-party wrangling, including by more generous counter-proposals from the now opposition KMT that has a majority in the legislative assembly. Pointing to Taiwan's current economic problems (unemployment at almost 3.19 per cent in December 2000 was an all time high), employers have protested against the proposal to reduce the work week from 44 hours per week to 84 hours per fortnight. 


\section{The Transitions in Korea and Taiwan Compared}

While Korea and Taiwan shared commonalities that distinguished them from the experiences of labour reform associated with neoliberalism, there also existed significant differences between the two in the course of their transition towards more market driven development strategies. In particular, the course of labour reform on market principles proceeded with far less damaging labour resistance and intellectual controversy in Taiwan. In Korea, labour flexibility reforms could only be properly introduced after the economic collapse of late 1997. The Korean state's approach was also more explicity inclusionary.

The Kim Young-Sam government, despite its slogan of globalization, sought to integrate the labour unions into a wider consensus for change. It formed a national deliberation panel consisting of representatives from the national labour federations, business, civic groups and academia. When the discussions became deadlocked, the hardline anti-labour elements in the government gained the ascendancy and this resulted in the introduction of a new labour law in December 1996 (passed in a secret session that excluded opposition legislators). ${ }^{34}$ The new law enshrined the principle of 'no work, no pay', and facilitated the introduction of a flexible working week, easier dismissal and the recruitment of temporary workers. ${ }^{35}$ It triggered two months of damaging strikes that helped to worsen what was already a severe export crisis associated with global over-capacity. Labour protest actions including the first general strike since 1948, were coordinated through the official FKTU and the unofficial KCTU. The protesters did not alter the central provisions of the December 1996 legislation but extracted concessions from government over the application of the law. These were contained in the revised version of the law passed in March 1997. For example, the government promised that dismissals would be sparingly applied (i.e. only after employers had exhausted all other alternatives). These major labour reforms would only become established in 1998 after the economy slipped into negative growth and the alternation of power.

${ }^{34}$ Byung-Kuk Kim and Hyun-Chin Lim, 'Korean Labour Against Itself: Structural Dilemmas of State Monism', in Larry Diamond and Byung-Kuk Kim, eds, Consolidating Democracy in South Korea (Boulder: Lynner Rienner, 2000), pp. 111-37, at pp. 130-1.

${ }^{35}$ Jong-Kyu Park, 'Chaegye wa nodonggye keukdanjuuiga pich'eun ch'ungdol' ['Confrontation Arising From Business and Labour Extremism'], Chosun Wolgan [Choseon Monthly], February (1997), pp. 91-9. 
Ironically, the key turning points in the weakening of labour resistance towards market reform took place after the alternation of power to leaderships historically seen as sympathetic to labour. In Korea, this occurred in August 1998 when workers of the Hyundai Motor Company (one of Korea's premier export plants) decided to accept the employer's lay off schedule. The decision set the tone of retreat for the rest of the union movement as labour forces turned their attention from job protection to severance compensation. ${ }^{36}$ In Taiwan, the new DPP government launched the privatization of Chunghua in summer 2000, despite having supported a moratorium in the election campaign a few months previously. With a well organized labour union, Chunghua became a crucial test case of labour resistance to privatization. Labour's insistence on job and wage guarantees (and stock options) meant that it could not elicit much public sympathy. ${ }^{37}$ Vocal mass demonstrations (including a 7,00O strong rally) were unable to prevent the government from going ahead with the programme in August 2000. The government made no secret of its plan for many more privatizations.

\section{Explaining the Variations}

The variations in the paths of marketization can be explained with reference to three sets of factors: economic structure, economic ideology and the wider context of political competition. The influence of these factors are summarized in Figure 3 .

Whilst appearing to be very similar (especially during the labourintensive stage), the growth strategies and their outcomes had by the 1990s, created rather different opportunities and constraints for the labour movements of Korea and Taiwan. The economic strategies of the two developmentalist regimes and the conceptions of economic nationalism that lay behind them pointed to different paths of evolution for the two labour movements. The Korean version was more conducive to unionization because of the prevalence of large scale plants and heavy industry concentrated around the chaebol. It was also more centrally directed and so labour disputes easily became politicized. Korea's development strategy involved more overt social

${ }^{36}$ Ho-Keun Song, 'Labour Unions in the Republic of Korea: Challenge and Choice', ILO Labour and Society Programme Discussion Paper DP/ Io 7/ I999, (1999), p. 29.

37 'Government Should be Firm with Chunghua', Taipei Times, (25 August 2000). 


\begin{tabular}{|c|c|c|}
\hline & KOREA & TAIWAN \\
\hline $\begin{array}{l}\text { Economic } \\
\text { structure and } \\
\text { strategy }\end{array}$ & $\begin{array}{l}\text { - Conglomeration } \\
\text { - Concerted heavy industrial } \\
\text { development }\end{array}$ & $\begin{array}{l}\text { - SMI dominant } \\
\text { - Moderation of heavy industrial } \\
\text { development from } 1976\end{array}$ \\
\hline Economic ideology & $\begin{array}{l}\text { - Maximize growth } \\
\text { - Industrialization self-sufficiency } \\
\text { 'match Japan' } \\
\text { - Influence of societal corporatism } \\
\text { model }\end{array}$ & $\begin{array}{l}\text { - Consistent and stable growth } \\
\text { - Integration with TNCs } \\
\text { - Predominance of neo-classical } \\
\text { economic models }\end{array}$ \\
\hline $\begin{array}{l}\text { Political } \\
\text { competition } \\
\text { context }\end{array}$ & $\begin{array}{l}\text { - Military regimes } \\
\text { - Centralized regime with no } \\
\text { institutional safety valves } \\
\text { - Opposition legitimized by } \\
\text { nationalist historical legacy }\end{array}$ & $\begin{array}{l}\text { - Single party-state } \\
\text { - High degree of institutionalization: } \\
\text { potential opposition channelled into } \\
\text { local politics } \\
\text { - Weak historical legacy of legitimate } \\
\text { opposition }\end{array}$ \\
\hline $\begin{array}{l}\text { International } \\
\text { context }\end{array}$ & $\begin{array}{l}\text { - Diplomatic ascendancy } \\
\text { - Hostility to TNCs } \\
\text { - Closure of North Korea } \\
\text { - Inflexible management style }\end{array}$ & $\begin{array}{l}\text { - Diplomatic weakness } \\
\text { - Open economics as surrogate form } \\
\text { of diplomacy } \\
\text { - Opportunities for industrial } \\
\text { relocation to mainland China } \\
\text { - Adaptable management style }\end{array}$ \\
\hline
\end{tabular}

Figure 3. Sources of Variation in the Paths of Labour Market Reform in Korea and Taiwan.

inequalities including business concentration, the squeeze on farmers and the existence of rigid hierarchies in large scale plants organized on military-style discipline. It also involved more serious economic dislocations in the form of higher inflation and sharper contractions in growth. These dysfunctionalities made Korean workers more receptive to politicization and radical influences (for example, from radical students deliberately infiltrating the shopfloor). With the economy so dependent on a few chaebol, Korean labour unions in those business groups were capable of exerting great disruptive influence.

By contrast, the prevalence of small and medium industry (SMI) in Taiwan was less conducive to the formation of 'stable proletarian communities' ${ }^{38}$ that was the basis of Korean unionization. It has been observed that because SMI and non-protected sectors do not generate monopoly rents, the incentive for assertive labour unionism (to gain

${ }^{38}$ Frederic C. Deyo, 'State and Labor: Modes of Political Exclusion in East Asian Development', in Frederic C. Deyo, ed., The Political Economy of the New Asian Industrialism (Ithaca, NY: Cornell University Press, 1987), pp. 182-202, at p. 196. 
a share of those rents) does not exist either. ${ }^{39}$ There was a state prioritized heavy industrial sector in Taiwan but it was smaller than Korea's (and on the whole efficiently run despite the prevalence of state ownership amongst such enterprises). The public ownership of strategic industries was due to Taiwan's lack of experienced industrialists and also to the regime's political reservations about 'big capitalism' (as a political challenge, as a source of social inequality and target of discontent like the Korean chaebol). Taiwan's phase of heavy industrialization was not as prolonged as Korea's, whose heavy industrial 'forced march' created too many protected industries (public and private) that were hyper-sensitive to growth fluctuations but politically difficult to dismantle. From 1976 (Seventh Plan 1976 81 ), the Taiwanese economy began its drive towards high technology while Korea persisted with heavy chemical industrialization (HCI).

Taiwan's developmentalism was more internationalized than Korea's. The prevalence of SMI and integration with TNGs meant that Taiwanese workers were less averse to market-oriented employment systems with their associated insecurities. Labour reactions to the partial privatizations of the China Steel Corporation (support) and China Petroleum Development Corporation (opposition) in 1989 pointed to the existence of pragmatic attitudes amongst Taiwanese workers even in the SOE sector, namely, motivation by the prospect for gain and security under the new arrangement. ${ }^{40}$ If anything, foreign corporations were preferred by Taiwanese workers. They were more generous in their remuneration while being no more aggressive than local employers in their managerial practices. Studies have shown job mobility (and the aspiration to become a small entrepreneur) to be deeply ingrained in the mentality of Taiwanese workers. ${ }^{41}$ Redundant workers tended to be more concerned about severance compensation than about preservation of the job itself.

That the vision of societal corporatism appealing to Koreans did not assume much policy significance in Taiwan can also be traced to the intellectual realm. We saw in the previous section that neo-liberal

${ }^{39} \mathrm{Ju}-\mathrm{Ho}$ Lee and Dae-Il Kim, Labour Market Developments and Reforms in Korea (Seoul: KDI, Working Paper 9703, 1997), p. 36.

${ }^{40}$ Agnes Syu, From Economic Miracle to Privcatization Success: Initial Stages of the Privatization Process in Two SOEs on Taiwan (Lanham, MD: University Press of America, 1995), pp. 174-7, 180-1.

${ }_{41}$ Joseph E. Lee, 'Economic Development and the Evolution of Industrial Relations in Taiwan, 1950-1993', in Anil Verma et al., eds, Employment Relations in the Growing Asian Economies (London: Routledge, 1995), pp. 88-1 18, at pp. 106-9. 
doctrines failed to achieve a dominant status in either Korea or Taiwan. Having said that, Taiwan's intellectual community was more accommodating to market principles than Korea's (even though 'globalization' was the official slogan in Seoul). In economics, the most influential of the social sciences, market models tended to dominate labour analysis amongst Taiwanese scholars whereas Korean ones were more inclined towards political economy. Indeed, Kim Dae-Jung has come under fire from Korean scholars for being too uncritical towards neo-liberalism. ${ }^{42}$ Discussions about labour issues by Taiwan's CLA and in academic labour studies were heavily oriented towards technical matters (like safety equipment).

The differences in the paths towards labour market reform were also shaped by the political dimensions of the developmental state and by the subsequent democratization processes. The KMT partystate in Taiwan represented a more penetrating and cohesive form of authoritarian regime than its counterpart in Korea. Modelled on a Leninist pattern, the KMT regime was thoroughly reorganized soon after its retreat from the Chinese mainland. ${ }^{43}$ Like other parts of the state, the CFL became interlocked with the ruling KMT. When the CFL did finally detach itself from the KMT in 2000, it could only do so at the cost of further fragmentation as two breakaway union groups emerged out of the CFL. With the existence of four national federations, the potential for labour union solidarity was badly damaged. ${ }^{44}$ By contrast, the Korean 'bureaucratic authoritarian' regime was not in place until the early 1960 . To the Japanese-trained colonial bureaucratic and police apparatus was added a US-trained military in the $195^{\circ}$ os (the Korean CIA was not established until 1961). By the time of the military seizure of power in 1961, civil dissent was once more on the upsurge (a vibrant student movement and the first attempts at independent labour organization since the anti-left purges of $1945^{-7}$ ). This dissent was temporarily demobilized during

42 e.g. Byung-Yong Ahn, 'Kimdaejung cheongbuga ppajilsu inneun shinjayujuui hamcheong' [The Kim Dae-Jung Government is Falling into the Trap of Neo-Liberalism], Shin Dong- $A$ [New East Asia], April (1999), 86-92; Man-Woo Lee, 'Konggieop minyeonghwa, idaero kwaench'anna' [Is the Privatization of Public Corporations Proceeding the Right Way?] in Shin Dong-A [New East Asia] February (1999), 368-76.

${ }^{43}$ Thomas B. Gold, State and Society in the Taiwan Miracle (Armonk, NY: M.E. Sharpe, 1986), pp. 59-64; Stephan Haggard and Robert Kaufman, The Political Economy of Democratic Transitions (Princeton: Princeton University Press, 1995), Ch. 8.

44 'Quanguo zhonggonghui yifen weisi' [National Labour Union Federations Split Four Ways], Zhongguo Shibao [China Times], (9July 2000). 
the 1960 s but not extinguished. Another source of opposition that the regime had to coexist with was the conservative opposition political parties. Military rule in Korea, suffered from the weakness of its 'institutionalization', that is, the capacity to make its rule legitimate by channelling political energies through the official institutions of representation. By the 1970 , elements of the conservative opposition (like Kim Dae-Jung in the 1971 election) were championing the labour cause. The issue also energized the dormant student movement. The official failure to enforce protective labour provisions also stoked up very extreme forms of labour protest (such as the Chun Tae-Il Incident of 1971 in which a labourer commited suicide by self-immolation). The ultra centralization of the Korean structure of government (i.e. everything in and from Seoul) also tended to focus dissent against the centre. By allowing a measure of political activity at the local level, the KMT succeeded in channelling the political energies of the hostile local Taiwanese population away from the regime that arrived from the mainland in $195^{\circ}$.

Taiwanese labour's comparative adaptiveness to market forces has also been shaped by the country's peculiar international circumstances. In particular, diplomatic isolation since the loss of UN status in 1971 and increasing vulnerability to mainland China have encouraged the Taiwanese state to become more accommodating to international trends. This has had positive and negative implications for labour. For example, placating US opinion was one factor shaping the passage of the LSL in 1984. Participation in international labour federations was also encouraged by the state as a form of quasi-diplomatic activity (for example, the CFL joined the International Confederation of Free Trade Unions). On the other hand, the search for diplomatic status via economic contacts also facilitated labour flexibility (for example in the form of official encouragement for the entry of TNCs). More recently, the diplomatic priority of securing WTO membership has outweighed any counter-arguments about job losses.

By contrast, the Korean state has not been forced to look to open economics as a surrogate form of diplomatic recognition. On the contrary, the achievement of economic and diplomatic superiority ${ }^{45}$ over communist North Korea by the early 1990 seemed to vindicate the neo-mercantile model. The entry of foreign capital was (and

${ }^{45}$ As confirmed by the joint entry of the Koreas into the UN in 1991, a move the North had long opposed. 
still is) viewed as a threat to national economic sovereignty. ${ }^{46}$ The nature of the principal diplomatic foe has also affected the labour issue differently in Korea and Taiwan. The liberalizing mainland Chinese economy has proved to be an irrestible magnet for Taiwanese business in search of flexible, cheap labour in a culturally familiar milieu (notwithstanding the political hostilities between the Taipei and Beijing). The Korean peninsula, on the other hand, is mired in an ideological stand off that leaves less space for private economic initiatives. In spite of the much talked about complementarity between South Korean capital and North Korean labour (not to mention Kim Dae-Jung's 'sunshine policy' of separating economics and politics), the transplantation of labour-intensive operations to the North has been limited by political constraints. Even when it has relocated overseas in areas like mainland China and Southeast Asia, Korean business adapted badly because of its authoritarian style. These factors have forced the Korean state to take a far more pro-active attitude towards fostering a tripartite social compact at home than its Taiwanese counterpart.

\section{Conclusion}

The recent evolution of the labour situation in Korea and Taiwan illuminates the debate about comparative transitions to neoliberalism. It highlights the importance of developmentalism's legacies of growth and an effective state in structuring the subsequent pathway of neo-liberalization. Governments in Korea and Taiwan have promoted the acceleration of labour market reform from the mid-1990s, but that change has been accompanied by distinctive political, economic and ideological features marking it out from neoliberal transitions elsewhere. Specific background conditions shaped a distinctive Northeast Asian path of accommodation with global neo-liberalism in the realm of labour market reform and labour relations. Even though Korea and Taiwan shared many common features when contrasted with developing capitalisms elsewhere, it is also apparent that Taiwan's labour relations adjusted more smoothly to the marketization drive than Korea's. This difference is consistent with previous experiences of political economic adjustment in response

\footnotetext{
${ }^{46}$ For example, in the fall of 1999, car workers of the bankrupt Daewoo group demonstrated in solidarity with their owners against the possible takeover of their subsidiary by US giant General Motors.
} 
to global systemic changes and can be understood when the cumulative divergences in political and economic practices over nearly three decades are taken into account.

There is an argument that neo-liberal democracy needs an effective, pro-active state capable of enforcing competition and correcting the deep social contradictions inherent to the system. In Latin America, the historical failures of statism, the power of transnationalized interests and the seriousness of the 'fiscal crisis' have prevented the state from fulfilling such a role. Instead, the Latin American state uses its coercive force to prevent social discontent from encroaching onto the private domains of the privileged. ${ }^{47}$ Not having been drastically pared back because of fiscal crisis, the Northeast Asian state has remained relatively intact and effective. The background of economic success means that there has been no upsurge of neo-liberal populism against discredited statism on the Latin American and Eastern European patterns. By contrast, mass and elite expectations that the state should correct economic and social ills remain firmly established in Northeast Asia. This has left more scope for the introduction of social measures that lessen the pain of labour market reform and for the promotion of labour's political rights.

The alternation of power in recent years has brought to power governments explicitly committed to developing such a hybrid approach in the name of 'democratic market economy' (Korea) or 'third way' (Taiwan). Having never been committed to socialism or statist-populism, Korea's Kim Dae-Jung and Taiwan's DPP did not face the problems of internal party management encountered by traditionally pro-statist parties elsewhere making the conversion to market economics. ${ }^{48}$ Strong doubts persist about the viability of this pathway of adaptation to neo-liberal globalization. These include

${ }^{47}$ Peter B. Evans, 'The Eclipse of the State?', World Politics, 5o, 1 (1997), pp. 62-87, at pp. 85-6; Guillermo O'Donnell, 'Poverty and Inequality in Latin America: Some Political Reflections', in Victor E. Tokman and Guillermo O'Donnell, eds, Poverty and Inequality in Latin America: Issues and New Challenges (Notre Dame: University of Notre Dame Press, 1990), pp. 49-71, at p. 59.

${ }^{48}$ e.g. Edward L. Gibson, 'The Populist Road to Market Reform: Policy and Electoral Coalitions in Mexico and Argentina', World Politics, 49, 3 (1997), pp. 339-70; Mick Moore, (1997) 'Leading the Left to the Right: Populist Coalitions and Economic Reform', World Development, 25, 7 (1997), pp. 10o9-28; Kay Burgess, (2000) 'Loyalty Dilemmas and Market Reform: Party-Union Alliances Under Stress in Mexico, Spain, and Venezuela', World Politics, 52 (2000), pp. 105-34; Victoria Murillo, 'From Populism to Neo-Liberalism: Labour Unions and Market Reform in Latin America', World Politics, $5^{2}$ (2000), pp. 135-74. 
doubts about the coherence of 'democratic market economy' and 'third way' type blueprints that were first developed as part of catchall strategies of oppositional mobilization, about the capacity of the democratic state to act as a balancer of contending interests that is capable of maintaining autonomy from big business, and the readiness of transnational investors to be 'incorporated' in any way. Time will tell whether these doubts are justified but what is clear from our analysis of labour is that there are tentative makings of a 'Northeast Asian pathway' of adaptation to the latest round of global systemic change. 